\title{
Kajian Korupsi sebagai Proses Sosial: Melacak Korupsi di Sektor Sumber Daya Alam di Indonesia
}

\author{
Wigke Capri, Devy Dhian Cahyati, Mahesti Hasanah, \\ Dias Prasongko, Wegik Prasetyo \\ Universitas Gadjah Mada \\ wigke.capri@ugm.ac.id,devy.d.c@ugm.ac.id,mahesti.hasanah@ugm.ac.id, \\ dzprasongko@mail.ugm.ac.id,wegikprasetyo@ugm.ac.id
}

\begin{abstract}
The study of corruption mostly focuses on either institutional corruption or uses an institutional approach to understand corruption. This research offers Social Network Analysis (SNA) to understand corruption better by focusing on actor networks and corruption exchange in two sectors: oil-gas and forestry in Indonesia. We collected six important findings, such as: corruption creates dependency amongst actors; corruption requires a strong social-network, involving multi-interests and resources exchange; repeating and interlocking relations in corruption acts; institutionalizing of corruption network; the institutionalized corruption binding private sector through bribery; and binding public sector through harmful regulations for social, economy, politics, or law impacts.
\end{abstract}

Keywords: Corruption, Social Network Analysis, Forestry, Oil and Gas, Natural Resource

\begin{abstract}
Abstrak
Studi korupsi seringkali memiliki fokus pada korupsi institusional atau menggunakan pendekatan institusional untuk memahami korupsi. Penelitian ini menawarkan untuk memahami korupsi lebih baik dengan menggunakan analisis jaringan sosial (SNA) dengan fokus pada jaringan aktor dan pertukaran korupsi di dua sektor; migas dan kehutanan di Indonesia. Penelitian ini memiliki enam temuan penting yaitu relasi ketergantungan yang tercipta dan terbentuk antar aktor, pertukaran sumber daya antar aktor menjadi syarat utama terjadinya tindak korupsi, aktor dalam tindakan korupsi adalah pihak yang memiliki jaringan kuat melibatkan multi kepentingan dan sumber daya, relasi korupsional terjadi berulang dan saling mengunci, jaringan korupsi membentuk institusi sendiri atau menciptakan pelembagaan koruptif, dan pelembagaan koruptif ini membelenggu sektor privat melalui mekanisme suap dan sektor publik dengan otoritas perizinan yang merugikan Indonesia baik dari sisi integritas, menggerogoti ekonomi, sistem sosial dan politik, dan hukum.
\end{abstract}

Kata Kunci: Korupsi, Analisa Jaringan Sosial, Kehutanan, Migas, Sumber Daya Alam 


\section{Pendahuluan \\ Latar Belakang}

Korupsi adalah aktivitas yang merugikan negara dan warga negara. Studi MacMullen (1988) menyebutkan korupsi sebagai faktor utama keruntuhan dari Kekaisaran Romawi. Korupsi menjadi penyakit yang sistemik baik dalam level lokal, nasional maupun global. Penyakit sistemik tersebut menyerang dan merugikan aspek dan lini penting negara.

Kajian-kajian korupsi menemukan bahwa korupsi memiliki dampak buruk bagi sumber daya politik, ekonomi, maupun sosial. Bagi sumber daya politik, korupsi menggerogoti kualitas institusi dan kepercayaan sosial (Bjørnskov, 2011), memperburuk kualitas demokrasi, kebebasan dan keterbukaan publik (Chowdhury, 2004; Johnston, 2005; Brunetti \& Weder, 2003; Rose-Ackerman \& Søreide, 2012; Gokcekus \& Knorich, 2006).

Sumber daya ekonomi pun tergerogoti karena korupsi. Pertumbuhan ekonomi pun melambat dan memunculkan ekonomi bayangan dalam sektor keuangan (Méon \& Sekkat, 2005; Mauro, 1995; Dreher \& Schneider, 2010), memperlambat bisnis dan menciptakan ketimpangan yang semakin lebar (Gokcekus \& Yuuki, 2011). Korupsi tidak hanya hadir di negara-negara berkembang namun, juga terjadi di negara-negara maju (Johnston, 2005; Khan 2000; RoseAckerman and Søreide, 2012). Berbeda dengan negara berkembang, praktik korupsi di negara maju tidak berada di birokrasi, politik atau pun institusi kepolisian, namun di sektor keuangan seperti yang terjadi di Britania Raya. Berdasarkan data peringkat korupsi Transparansi International (2019), Britania Raya menduduki peringkat ke-12. Berdasarkan ahli keuangan dan kriminal Roberto Saviano (2017) Britania Raya menduduki peringkat pertama korupsi di sektor keuangan.

Selain merugikan sumber daya politik dan ekonomi, korupsi juga merugikan sumber daya sosial. Penelitian Niklas Potrafke (2011) di 125 negara menemukan bahwa warga negara di negara yang angka korupsinya rendah memiliki tingkat intelegensi (IQ) yang tinggi.

Di Indonesia, tindak kasus korupsi dalam data putusan tetap (inkracht) Komisi Pemberantasan Korupsi (KPK) dari tahun 2014 hingga 2020 tercatat mencapai 522 putusan. Dari 522 putusan tersebut, korupsi di sektor sumber daya alam (SDA) hanya mencapai 24 putusan atau $4,6 \%$ saja. Penanganan tindak korupsi di sektor SDA ini perlu mendapat perhatian yang besar. Menurut penelitian KPK dengan Publish What You Pay (PWYP) Indonesia (Abdullah, 2017) masih terdapat permasalahan dalam tata kelola Penerimaan Negara Bukan Pajak (PNPB) dan berpotensi mempengaruhi pendapatan negara dari PNPB. Permasalahan tersebut dimulai dari tunggakan pembayaran PNBP, pungutan tanpa dasar hukum hingga tidak validnya perhitungan kandungan batu bara dan mineral (KPK, 2018). Semua ini menjadi basis royalti bagi negara. Pada tahun 2018, total PNBP mencapai Rp 217,5 triliun atau 53,4 persen dari total keseluruhan PNBP yang diterima negara (Akbar, 2019).

Sejak 2009, Komisi Pemberantasan Korupsi (KPK) pun telah melakukan berbagai upaya untuk menindak korupsi sektor SDA (acch.kpk.go.id). KPK bekerja sama dengan pemerintah, akademisi dan masyarakat sipil membangun kampanye antikorupsi melalui Gerakan Nasional Penyelamatan Sumber Daya Alam (GNPSDA). Selain itu, KPK mengeluarkan Roadmap Pemberantasan Korupsi tahun 2012-2023 mengarusutamakan perhatian 
pada korupsi di sektor SDA (KPK, 2011). Melalui Gerakan dan peta jalan (roadmap) ini, KPK berhasil menangani 27 kasus tindak korupsi SDA selama sepuluh tahun terakhir (Tempo, 2020). Salah satu upaya KPK dalam merangkul akademisi untuk memerangi korupsi adalah mengadakan acara tahunan Anti-Corruption Summit (ACS). Terakhir, KPK membuat Jurnal Volume 5 Nomor 2 tahun 2019 yang memuat edisi khusus tentang korupsi dan SDA di Indonesia. Dalam jurnal tersebut, Muhajir (2020) menganalisis kelemahan kebijakan korupsi di Indonesia dari pendekatan institusional dan prosedural.

Meski sejumlah usaha telah dilakukan dalam memberantas korupsi di sektor SDA, tindakan korupsi yang seringkali dilakukan secara sembunyi-sembunyi tetap sulit untuk dideteksi. Keterbatasan dalam menangani isu korupsi SDA seperti sulitnya mencari bukti yang kuat hingga tak terkait langsung dengan adanya unsur kerugian negara menjadi tantangan pemberantasan korupsi di sektor ini. Karena itu, penelitian korupsi di sektor SDA diharapkan bisa membantu dalam memetakan dan melihat pola tindak korupsi di sektor ini sehingga meminimalisir tindak korupsi yang akan datang. Apabila korupsi mampu diminimalisir maka diharapkan penerimaan negara mengalami peningkatan. Peningkatan PDB akan berimplikasi tidak hanya terhadap perekonomian namun juga menciptakan sistem politik yang bersih, memperkuat sistem sosial dan mengurangi kemiskinan. Implikasinya tingkat kecerdasan masyarakat Indonesia meningkat dan mampu bersaing di tingkat global.

\section{Rumusan Masalah}

Berdasarkan kajian-kajian tersebut tulisan ini ingin menjawab dua pertanyaan penting yaitu:

1. Bagaimana relasi antar aktor dala m korupsi SDA?

2. Apa saja yang dipertukarkan dalam korupsi SDA?

\section{Tujuan Penelitian}

Tujuan dari tulisan ini adalah pertama, menelusuri dan melacak jaringan korupsi di sektor SDA berbasis aktor dan apa yang dipertukarkan. Selain itu, tulisan ini memiliki tujuan utama untuk mendorong penelitian studi korupsi dengan menggunakan Analisis Jaringan Sosial. Penelitian menggunakan Analisis Jaringan Sosial memang bukanlah hal yan baru, namun masih terbatas digunakan dalam studi korupsi khususnya korupsi SDA di Indonesia. Tulisan ini terinspirasi dari tulisan Jacqui Baker (2020) tentang "Jaringan Korupsi di Sektor Kehutanan Indonesia: Politik dan Pulp di Palalawan, Riau" yang menjadi studi awal dari studi korupsi SDA dengan menggunakan Analisis Jaringan Sosial.

Tulisan ini juga memuat protokol dalam melakukan analisis korupsi dengan memanfaatkan Analisis Jaringan Sosial yang dapat ditemukan dalam keterangan.

\section{Penelitian Terdahulu}

Studi-studi korupsi banyak menggunakan tiga pendekatan utama yaitu pendekatan ekonomis atau pendekatan rasional, pendekatan kultural, dan pendekatan neo-institusional (Vannucci, 2015:1). Pendekatan rasional berpandangan bahwa manusia sebagai makhluk rasional yang mengharapkan adanya "ongkos" dan imbalan. Menurut Larmour dan Wolanin (2013), pendekatan ekonomi rasional mengasumsikan bahwa setiap individu adalah makhluk rasional dan senantiasa menghitung rugi dan 
untung. Untuk itu, skema insentif dan disentif seringkali menjadi aturan untuk mencegah terjadinya korupsi. Studi Mietzner (2015) menunjukkan praktik korupsi di ranah politik terjadi secara luas karena unsur kesengajaan kesengajaan elit sebagai makhluk rasional. Situasi ini terjadi karena lemahnya institusi partai politik dan sistem finansial politik untuk mencegah dan mengontrol terjadinya korupsi.

Pendekatan kultural melihat perbedaan tradisi, norma sosial, dan internalisasi nilai yang membentuk preferensi moral, pertimbangan sosial dan institusi. Pendekatan kultural melihat korupsi sebagai tradisi yang telah mengakar kuat di masyarakat. Studi-studi ini biasa dilakukan di negara-negara berkembang karena adanya ada budaya memberi hadiah sebagai aturan dalam suku atau keluarga besar (Larmour dan Wolanin, 2013:xi). Studi Mukartono, Hartiwiningsih \& Muhammad Rustamaji (2019) menjelaskan bahwa praktik korupsi merupakan proses yang berlangsung lama dan antar generasi sejak masa kolonial, Orde Lama dan menguat di era Orde Baru dan era reformasi. Penjelasan kultural dari fenomena korupsi berakar dari budaya Jawa kuno di mana pertukaran hadiah merupakan norma bisnis dan bukan bentuk penyuapan, serta loyalitas pada keluarga dianggap lebih penting dibanding loyalitas pada negara (Robertson-Snape, 1999).

Pendekatan neo-institusional melihat adanya mekanisme dalam aturan internal interaksi sosial dalam jaringan yang korup dan memiliki efek terhadap keyakinan dan preferensi seseorang (Vannucci, 2015; Dupuy,). Ganie-Rochman dan Achwan (2016) menggunakan pendekatan institusi organisasional untuk melihat praktik korupsi melintang dalam struktur dan mekanisme sebuah organisasi yang melibatkan aktor-aktor di dalamnya dan membentuk jejaring.

\section{Korupsi dalam konsep jaringan dan pola relasional}

Tulisan ini menggunakan konsep korupsi dari Warburton (2013) dan meminjam teori jaringan horizontal dari Marsh dan Rhodes (Rhodes \& Marsh, 1992; Rhodes, 1997). Warburton (2013) menjelaskan korupsi sebagai proses sosial dengan melihat pentingnya melakukan analisa aktor, keagenan, dan motivasi tindakan korupsi. Sementara konsep jaringan horizontal dari Rhodes dan Marsh (1992; 1997) membantu untuk menjelaskan jaringan antar aktor, dan sumber daya yang dipertukarkan antar aktor itu dalam tindakan korupsi.

Kerangka ini dipilih di tengah dominasi pendekatan institusional dalam studi korupsi di sektor SDA (Hellmann, 2017; Stevens, 2016; Robbins, 2017; Ganie-Rochman \& Achwan, 2016; Kartodiharjo, et. all., 2019; Mietzner, 2015). Padahal, pendekatan insitusional seringkali abai terhadap aspek aktor dan relasi antar aktor yang turut berkontribusi terhadap langgengnya praktik korupsi.

Pendekatan Warburton melihat korupsi sebagai proses sosial bukanlah pendekatan yang baru. Pendekatan ini berasal dari pendekatan keagenan dalam memahami korupsi. Menariknya, Warburton (2013) tidak membatasi interaksi keagenan ini dalam lingkup pejabat publik atau pejabat privat, keagenan dalam skope individu atau keagenan dalam skope kolektif. Bagi Warburton (2013) maupun Mahanti \& Dressler (2014) korupsi bisa dipahami sebagai proses sosial dimana terdapat dua hal utama yaitu pertama interaksi antar aktor baik individu maupun sekelompok individu, antar institusi baik publik 
maupun privat, antar organisasi. Kedua, ada pertukaran baik berupa kepentingan maupun kapital. Pendekatan ini memahami sistem sosial sebagai sistem yang dinamis bukan statis. Dinamika ini adalah manifestasi dari relasi kuasa dan interseksi dari hubungan antar aktor, institusi, maupun organisasi.

Warburton (2013) berargumen bahwa untuk memahami korupsi sebagai proses sosial, kita perlu menyadari dan memahami pola relasional antar aktoraktor individual. Aktor-aktor individual ini berperan sebagai partisipan dalam sistem sosial. Ini artinya, sistem sosial politik bukanlah sistem yang statis namun dinamis karena relasi sosial sarat dengan manifestasi relasi kuasa. Lebih lanjut, studi To, P. X., Mahanty, S., \& Dressler, W. (2014) menjelaskan bahwa korupsi melekat pada proses sosial melalui interaksi dan hubungan keseharian yang bertujuan untuk memudahkan interkoneksi antara kepentingan sosial, politik dan ekonomi.

Apabila pejabat publik, baik yang dipilih maupun ditunjuk, menggunakan kekuasaan mereka sebagai pemegang otoritas publik demi meraih kepentingan mereka sendiri dan dengan sengaja mengabaikan kepentingan publik maka ini disebut sebagai korupsi (Warburton, 2013). Korupsi tidak hanya terbatas di institusi pemerintahan namun juga melibatkan aktor-aktor sektor privat atau pasar. Tindakan-tindakan aktor sektor privat yang bertransaksi dengan pejabat public dengan saling menukarkan sumber kekuasaan. Aktor di sektor privat menyediakan sumber-sumber kekuasaan yang diinginkan pejabat publik, pejabat publik mengkonversi otoritas yang dimilikinya untuk kepentingan aktor di sektor privat dengan mengedepankan kepentingan aktor-aktor di sektor privat dibandingkan dengan kepentingan publik.

Dalam transaksi korupsi tersebut, komunikasi antara dua atau lebih individu menjadi medium penting terjadinya korupsi. Setiap individu memiliki kecenderungan untuk turut serta dalam transaksi korupsi (Warburton, 2013). Korupsi sudah seperti "unwritten rules of the game" bagi para pebisnis dan aparatur negara (Osburg, 2018). Pergi minum, pergi karaoke, atau bermain mahjong di kedai bersama dengan aparatur negara merupakan hal yang wajar. Dengan kata lain, proses relasi sosial dari kegiatan hiburan tersebut terjalin berdasarkan suatu kepentingan tertentu. Hal ini dapat mengaburkan mengaburkan proses korupsi karena dibalut dengan budaya sosial dan ass kekeluargaan. Selanjutnya, interaksi sosial lain yang sarat akan praktik korupsi adalah perkumpulan keluarga, bisnis, ataupun suatu profesi (Osburg, 2018). Agenda makan malam suatu kelompok bisnis menjadi sarana untuk bertukar informasi, menyediakan bantuan material dan non material, hingga ajang perkenalan klien baru. Poin terakhir menjadi sorotan tersendiri. Pasalnya, anggota baru harus berhadapan dengan relasi sosial yang sedemikian rupa dan akhirnya membuat individu tersebut mempraktikkan budaya korup.

Relasi saling mengkonversi kewenangan dan kepentingan ini disebut sebagai transaksi korupsi (Warburton, 2013). Transaksi korupsi ini melibatkan jejaring pertemanan maupun keluarga dengan mengandalkan kepercayaan (trust). Studi To, P. X., Mahanty, S., \& Dressler, W. (2014) menegaskan bahwa transaksi korupsi melibatkan jejaring yang kompleks dari tingkat lokal ke nasional. Selain itu, aktor yang terlibat juga memiliki identitas yang ambigu dan dinamis, terkadang mewakili negara namun di waktu yang lain mewakili privat atau kepentingan bisnisnya sendiri. Studi ini menunjukkan bahwa aktor "privat" dan "negara" tidak bisa ditempatkan secara biner sebagaimana studi korupsi yang 
normatif (To, P. X., Mahanty, S., \& Dressler, W., 2014).

Shleifer dan Vishny menemukan bahwa korupsi terjadi karena ada proses transaksi antara birokrasi dan pengusaha. Transaksi ini dilatarbelakangi unsur interdependensi di antara birokrasi dan pengusaha. Shleifer dan Vishny (1993) memberikan contoh dalam organisasi bisnis. Di satu sisi, birokrasi memiliki suplai atau otoritas sumber daya usaha, seperti pemberian izin. Di sisi lainnya, pengusaha membutuhkan unsurunsur tersebut untuk menjalankan usahanya.

Regulator menjadi aktor penting dalam transaksi korupsi. Studi Miller (2011) menjelaskan regulator memiliki peran dalam melanggengkan korupsi di sektor kehutanan melalui beberapa aktivitas ilegal, misalnya membiarkan orang untuk mengambil kayu tanpa dokumen yang sah maupun mempermudah proses administrasi dalam pemberian izin dengan imbalan uang. Transaksi korupsi dilatarbelakangi oleh beberapa hal yaitu gaji yang rendah, kebutuhan material regulator tidak terpenuhi (misalnya fasilitas penunjang), kurangnya kontrol dari pemerintah, dan jejaring pertemanan antara regulator dan sektor privat (Miller, 2011).

Palmer, D. (2008) mengatakan bahwa praktik korupsi bersumber pada adanya perilaku perilaku ketidakjujuran atau ilegal yang terjadi secara kolektif (organizational wrongdoing). Penulis mengenalkan istilah process model of collective corruption yang merupakan ekstensifikasi dari dua pendekatan yakni rational cost/benefit analysis dan normative appropriateness assessment views. Menurut Palmer, organizational wrongdoing dengan pendekatan collective corruption lebih memperhatikan adanya fakta bahwa collective wrongdoing sangat melibatkan adanya proses sosial.
Selain itu, Palmer juga memperhatikan adanya processual character dari perilaku kolektif tersebut. Artinya, perilaku tidak jujur menyebar dari satu invidu ke yang lain dari waktu ke waktu dan mereka terlibat di dalamnya dari waktu ke waktu. Ketiga, individu yang terlibat sehingga bisa mengamini ide wrongdoing itu dilakukan tanpa hati-hati atau lalai dan dipikirkan (mindfless/heedless) serta serta dilakukan dengan rasional.

De Graaf dan Huberts (2008) berkesimpulan bahwa korupsi biasanya muncul dalam hubungan yang abadi. Artinya hubungan tersebut dibangun dan dilanggengkan secara terus-menerus. Relasi yang ada menjadi korup karena ada proses yang disebut "a slippery slope", di mana pejabat yang melakukan korupsi sekali akan cenderung melakukannya lagi hingga susah berhenti.

\section{Metode Penelitian}

Tulisan ini menggunakan metode kualitatif selama sebulan dengan menggunakan alat bantu Analisis Jaringan Sosial (Social Network Analysis-SNA). SNA membantu untuk menemukan relasi, memetakan dan menemukan apa yang dipertukarkan dalam relasi koruptif tersebut. Baker (2020) berargumen bahwa SNA adalah alat bantu untuk memahami sistem sosial yang dibangun dari relasi atau simpul antar aktor.

Untuk mendapatkan relasi atau simpul aktor, peneliti melakukan pengumpulan dan pelacakan data dari tiga dokumen-dokumen publik yang telah dirilisi KPK dan MA dari tahun 2014 hingga Maret 2020. Tiga dokumen publik tersebut adalah:

1. Perkara yang berkekuatan hukum tetap/inkracht dari tahun 20142019 yang berjumlah 522 putusan.

2. Data jejak kasus di website KPK. 
3. Putusan Mahkamah Agung (MA) berbasis kasus dalam keputusan inkracht KPK.

Dari data putusan tetap sebanyak 522, peneliti menemukan 24 putusan korupsi di sektor SDA yang terhubung dalam 11 kasus korupsi dalam sektor kehutanan dan migas. Jumlah tersebut setara dengan $4,6 \%$ dari keseluruhan putusan perkara inkracht dalam kurun waktu lima tahun terakhir.

Sebelas kasus tersebut kami lacak dan menemukan jaringan yang terhubung dalam lima kasus tindak korupsi yaitu

1. Kasus Korupsi Nomor 1: Limbah Sawit Kalimantan Tengah

2. Kasus Korupsi Nomor 2: Jual-Beli Gas Alam Bangkalan

3. Kasus Korupsi Nomor 3: Tukar Guling Kawasan Hutan Bogor

4. Kasus Korupsi Nomor 4: Kasus Korupsi Sawit Kutai Kartanegara

5. Kasus Korupsi No. 5: Suap PT KPI (KPI) dan PT KOI kepada Kepala Kegiatan Usaha Hulu Minyak dan Gas Bumi SKK Migas.

Dari kelima tindak korupsi tersebut kami melacak dan memetakan relasi atau simpul korupsi sekaligus melacak pertukaran antar aktor.

\section{Analisis jaringan sosial: peta jaringan sektor sumber daya alam di Indonesia}

Kelima kasus tindak korupsi tersebut kami pisahkan dalam dua bentuk jaringan; jaringan aktor dan jaringan pertukaran. Dalam peta jaringan korupsi SNA, angka merepresentasikan aktor dan garis merepresentasikan relasi antar aktor. Tebal dan tipis garis menunjukkan intensitas relasi dari antar aktor tersebut. Sementara warna dari garis menunjukkan detail hubungan institusi dan pertukaran antar aktor. Untuk membantu peneliti dalam menganalisa sentralitas dalam SNA, kami merujuk Hafner-Burton et.all (2010). Hafner-Burton dkk (2011) mengilustrasikan sentralitas posisi aktor ke dalam tiga relasi yaitu derajat (degree), kedekatan (closeness), dan sentralitas aktor (betweenness). Ketiga relasi ini mengilustrasikan keuntungan politik dari masing-masing aktor. Derajad sentralitas (degree centrality) mengilustrasikan besarnya/banyaknya relasi kuat yang dimiliki aktor tersebut dengan aktor-aktor yang lain.

Aktor yang memiliki derajad sentralitas tinggi mengindikasikan aktor tersebut memiliki akses ke aktor-aktor kunci. Relasi kedua yang digambarkan melalui sentralitas aktor mengilustrasikan kemampuan aktor tersebut dalam menghubungkan aktor satu dengan yang lain atau biasa disebut dengan aktor yang berperan sebagai broker. Sementara kedekatan sentralitas mengilustrasikan bahwa aktor ini adalah aktor potensial yang memiliki kekuasaan dan kemampuan untuk mentransfer alat yang dipertukarkan atau sumber daya dari aktor satu ke aktor lain.

Relasi atau simpul antar aktor dengan ilustrasi garis ini memiliki banyak variasi. Peneliti mengindentifikasi lima relasi yang dibedakan dalam lima warna. Relasi pertama berwarna biru muda yang menunjukkan relasi antar aktor dengan institusi, relasi kedua berwarna hijau yaitu relasi antar aktor yang berasal dari institusi yang sama, relasi ketiga adalah relasi antar aktor yang memiliki relasi kekerabatan/kekeluargaan berwarna merah dan relasi berwarna orange yang menjelaskan tentang relasi otoritas aktor terhadap aktor lain dengan memerintah.

Selain lima relasi atau simpul, kami mengindentifikasi dua relasi pertukaran dengan warna ungu untuk memberi/menerima suap atau materi lain dan warna kuning untuk pertukaran 
berupa pencucian uang. Selain itu, kami juga memetakan warna garis merah untuk transaksi/pertukaran materi/dan lainnya dan warna abu-abu untuk hubungan pertukaran non-materiil.

\section{Pembahasan}

\section{Kasus Korupsi Nomor 1: Limbah Sawit Kalimantan Tengah}

Kasus ini bermula dari adanya temuan pencemaran limbah sawit di Danau Sembuluh, Kalimatan Tengah. Limbah tersebut diduga merupakan limbah dari anak usaha milik Grup Sinarmas. Dari sana, sejumlah pejabat

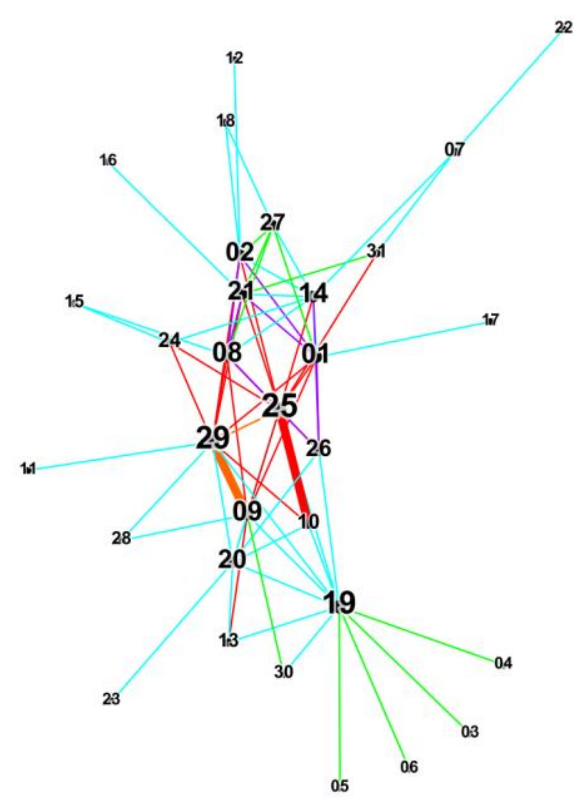

perusahaan kemudian melakukan penyuapan supaya anggota DPRD Kalimatan Tengah untuk tidak mengelar Rapat Dengar Pendapat (RDP) mengenai adanya permasalahan pencemaran limbah. Selain itu, penyuapan juga dilakukan supaya DPRD tidak mempersoalkan tidak adanya sejumlah izin milik PT BAP.

Hasil analisis menggunakan SNA menunjukkan bahwa TDSZ (25) merupakan aktor dengan derajad sentralitas tertinggi. Dalam peta SNA, aktor ini memiliki garis penghubung aktivitas paling tebal dengan nomor yang juga terlihat paling besar. Hal ini memperlihatkan bahwa 25 menjadi

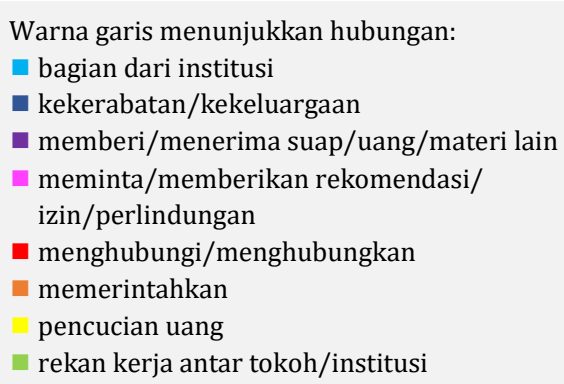

Grafik 1. Analisa jaringan aktor tindak korupsi limbah sawit di Kalimantan Tengah

aktor sentral yang banyak memiliki keterkaitan atau ikatan dengan berbagai aktor dalam jejaring aktor yang terjerat dalam semesta korupsi suap terhadap Komisi B DPRD Kalimantan Tengah. Singkatnya, 25 menjadi aktor sentral yang menjadi penghubung berbagai aktor dan mampu mengendalikan jaringan ini. Saat persidangan bergulir, 25 menjabat sebagai Department Head Document and License Perkebunan PT S Wilayah Kalimantan Tengah-Utara.
Tak hanya itu, peta SNA juga menjelaskan bahwa 25 bersama dengan WAA (29) memiliki memiliki derajad kedekatan sentralitas tertinggi. Hal ini berarti, baik 25 maupun 29 merupakan aktor yang memiliki rentang jarak aktivtas yang cenderung dekat dengan berbagai aktor. Posisi ini menunjukkan bahwa aktor tersebut merupakan aktor yang aktivitasnya relatif dekat dengan aktivitas aktor lain yang ada dalam jejaring kasus korupsi. Saat kasus ini masuk dalam 
persidangan, 29 menjabat sebagai Direktur Operasional PT S Wilayah Kalimantan Tengah IV, V dan GM yang pada saat bersamaan juga menjabat sebagai Chief Executive Officer (CEO) Perkebunan PT S untuk wilayah Kalimantan Tengah-Utara.

Sementara itu, 29 juga tercatat memiliki degree, betweenness, centrality tertinggi dalam kasus ini. Identifikasi ini berhasil tergambar pada peta jejaring aktor SNA karena aktor tersebut mampu berperan sebagai "middleman" atau yang menjadi jembatan bagi keberadaan aktoraktor atau dengan grup organisasi yang lain. Dalam kasus ini, aktor 29 mampu menjadi penjembatan antara para petinggi

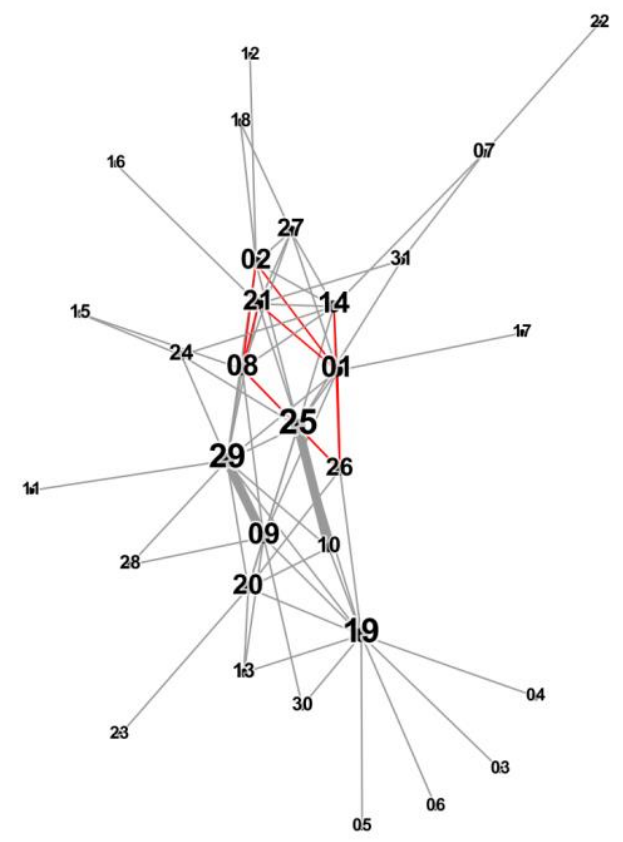

perusahaan sawit dengan pengambil kebijakan dalam kasus ini adalah DPRD Kalimatan Tengah.

Lebih lanjut, dalam peta SNA yang fokus pada materi pertukaran antara dua kelompok organisasi yakni DPRD dan juga anak usaha PT S sebagai perusahaan sawit, terlihat aktor 25 menjadi aktor penting dalam proses pertukaran sumber daya. Dalam hal ini, aktor 25 dibantu oleh staf PT BAP TAK (26) yang tergambar dalam lewat aktivitas garis berwarna merah pada peta jejaring SNA. Garis merah tersebut menandakan bahwa aktivitas pertukaran diantara dua organisasi atau aktor lain tersebut melewati sejumlah aktor mulai dari 25, 26,
Warna garis menunjukkan hubungan:

- transaksi/pertukaran materi/lainnya

n selain pertukaran

Grafik 2. Analisa jaringan pertukaran antar aktor dalam tindak korupsi limbah sawit di Kalimantan Tengah

01, 14, 02, 21 dan 08. Dalam hal ini, aktor 29 menjadi aktor yang dilewati karena aktivitasnya yang berkaitan permintaan izin yang dipertukarkan dengan uang suap.

\section{Kasus Korupsi Nomor 2: Jual-Beli Gas Alam Bangkalan}

Kasus ini bermula dari adanya keinginan dari PT MKS untuk memuluskan langkah perusahaan dalam usaha jual beli gas alam yang ada di Blok Poleng Bangkalan dengan PT KE co. Ltd. Dalam kasus ini, Direktur Human Resource Development PT MKS ABD (06) dijatuhi hukuman tiga tahun penjara karena terbukti melakukan penyuapan. Selain Antonius, ada nama lain yang juga terbukti melakukan korupsi, yakni Bupati Bangkalan periode 2003-20013 yaitu FAI (10). 

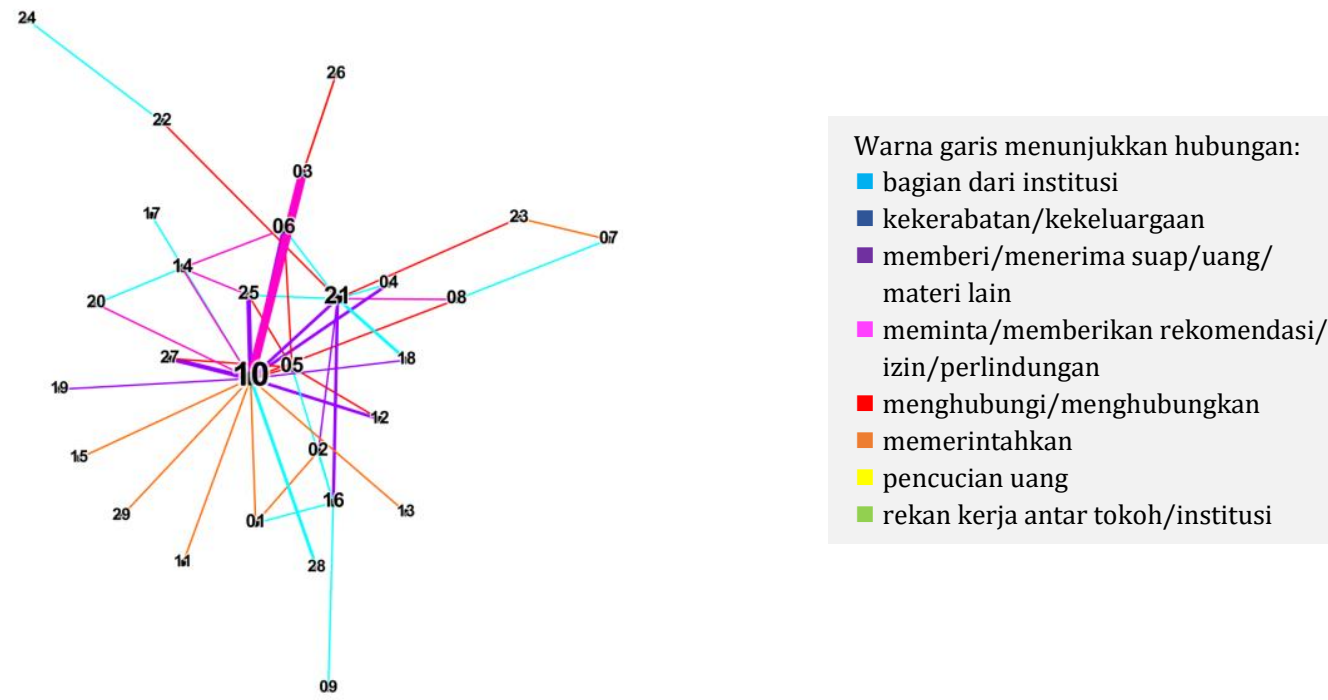

Grafik 3. Analisa jaringan aktor dalam tindak korupsi jual beli gas alam di Bangkalan

Hasil analisis dari peta SNA mencatat bahwa aktor 10 mendapat hasil tinggi dari ketiga indikator yakni derajad sentralitas, sentralitas aktor dan kedekatan sentralitas. Ini artinya, aktor 10 tersebut merupakan aktor yang sangat sentral dan sekaligus memegang peranan penting dalam jejaring praktik korupsi. Posisi sentral dari aktor 10 tersebut tergambar jelas lewat garis tebal berwarna merah muda yang terhubung ke sejumlah aktor lain yang juga ditetapkan sebagai terdakwa seperti 06 dan AR(03) yang juga merupakan adik ipar aktor 10 .

Selain itu, lewat peta jejaring SNA yang fokus pada pertukaran sumberdaya tersebut juga tergambar bahwa aktor 10 memiliki relasi langsung dengan sejumlah organisasi awal yang memberikan suap dalam hal ini PT MKS (21) dan PT KE co. Ltd. (21). Relasi langsung terkait dengan sejumlah pemberian izin yang harus melewati aktor 10 sebagai titik sentral dengan sumber daya yang dipertukarkan yakni pemberian suap.
Lebih lanjut, perlu penjelasan yang lebih komprehensif mengenai konteks yang lebih luas untuk menjelaskan sentralnya dari peran aktor 10 dalam jejaring korupsi. Kendati demikian, keseluruhan indikator yang tinggi pada aktor 10 tersebut bisa memiliki penjelasan bahwa relasi aktor 10 sangat mendominasi, seperti ditunjukkan lewat garis tebal berwarna merah muda dengan akto nomor 06 dan 03. Hal ini juga dikuatkan dengan adanya pertukaran "kepentingan" yang ditunjukkan lewat setoran uang dari perusahaan kepada aktor 10, telah dilakukan secara terusmenerus dalam rentang waktu yang cukup lama dan konsisten. Selain itu, hal ini juga mungkin berarti bahwa jaringan aktor ini cenderung ekslusif dan hanya terjadi di antara para aktor itu sekaligus dua institusi atau organisasi di belakangnya serta mendapatkan keuntungan dari relasi ini. 


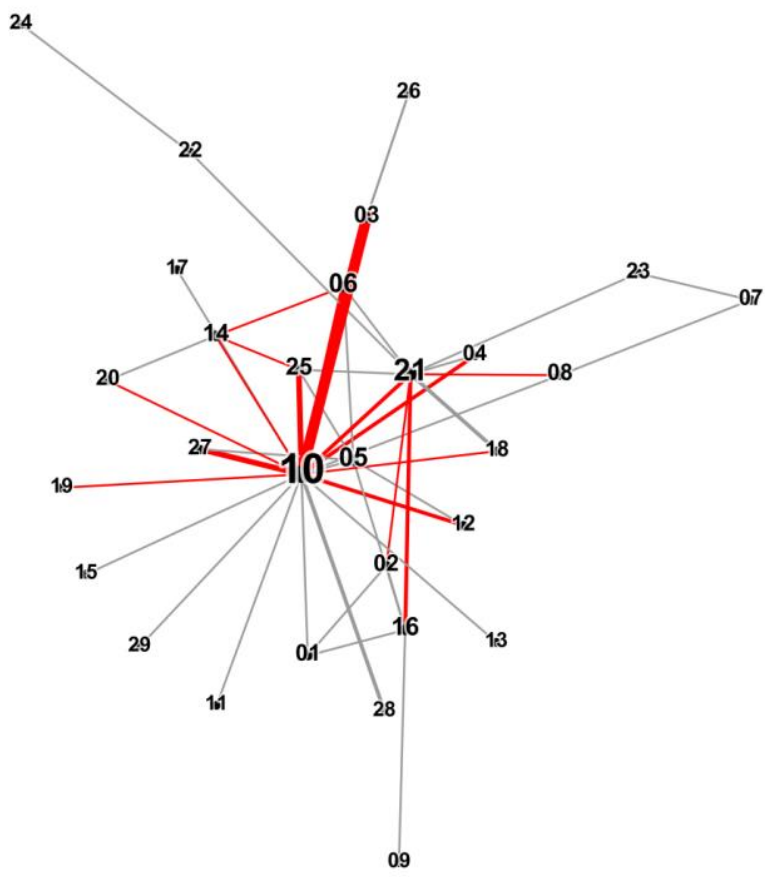

Warna garis menunjukkan hubungan: - transaksi/pertukaran materi/lainnya - selain pertukaran

Grafik 4. Analisa jaringan pertukaran antar aktor dalam tindak korupsi jual beli gas alam di Bangkalan

\section{Kasus Korupsi Nomor 3: Tukar Guling Kawasan Hutan Bogor}

Kasus tukar guling ini bermula dari rencana Presiden Komisaris PT BJA KCK (No. 17) yang ingin mempercepat terbitnya rekomendasi tukar menukar kawasan hutan seluas 2.754 ha di Kabupaten Bogor. Rekomendasi itu diperlukan sebagai satu syarat untuk memanfaatkan lahan tersebut sebagai bagian dari pembangunan kota satelit di kawasan Jonggol, Bogor. Untuk melancarkan usahanya tersebut Aktor No. 17 kemudian menyuap mantan Bupati Bogor 2008-2013 yaitu RY (No. 26).

Hasil analisa dari SNA menunjukkan bahwa aktor No. 17 selaku pemilik perusahaan menjadi aktor paling dominan dalam kasus suap tukar guling ini. Hal ini ditunjukkan lewat tingginya angka derajad sentralitas, sentralitas aktor dan juga kedekatan sentralitas. Aktor No. 17 ini menjadi simpul sekaligus titik utama di mana relasi praktik korupsi dengan sejumlah pejabat terbentuk. Aktor No. 17 terbukti telah menggerakkan sejumlah karyawannya No. 10, 12, 13, 14, 15, 28, 29, $30,31,32,33,34,35$, dan 36. Selanjutnya, karyawan tersebut diarahkan untuk membela aktor No. 17 dalam persidangan. Sementara itu, aktor No. 17 juga mengarahkan aktor No. 10 untuk berhubungan dengan sejumlah pejabat, termasuk mantan bupati Bogor, aktor No. 26. Sehingga, aktor No. 17 dan No. 10 menjadi bagian tak terpisahkan sebagai sentral di mana relasi korupsi dimulai.

Sedangkan simpul kedua terjadi dari aktor yang berasal dari institusi formal, yakni mantan Bupati Bogor (No. 26). Mantan Bupati Bogor tersebut, mendapat angka kedekatan kedua tertinggi setelah aktor No. 17, yang mengindikasikan bahwa dirinya memiliki jarak terdekat di antara semua aktor yang terlibat dalam jejaring korupsi. 


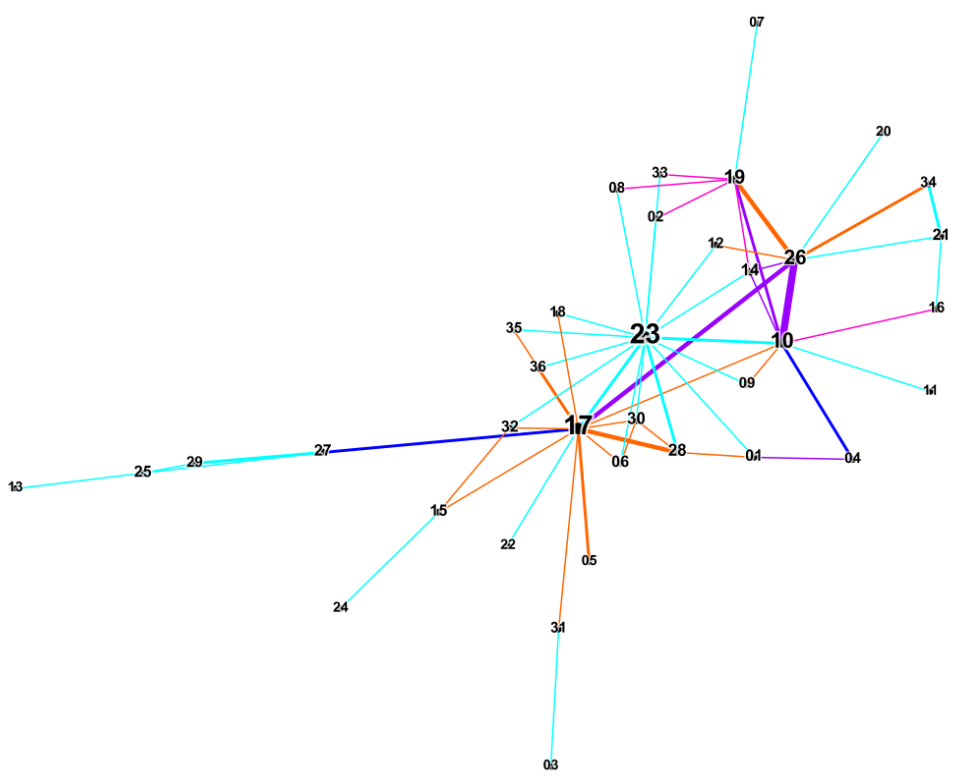

Grafik 5. Analisa jaringan aktor dalam tindak korupsi tukar guling kawasan hutan Bogor

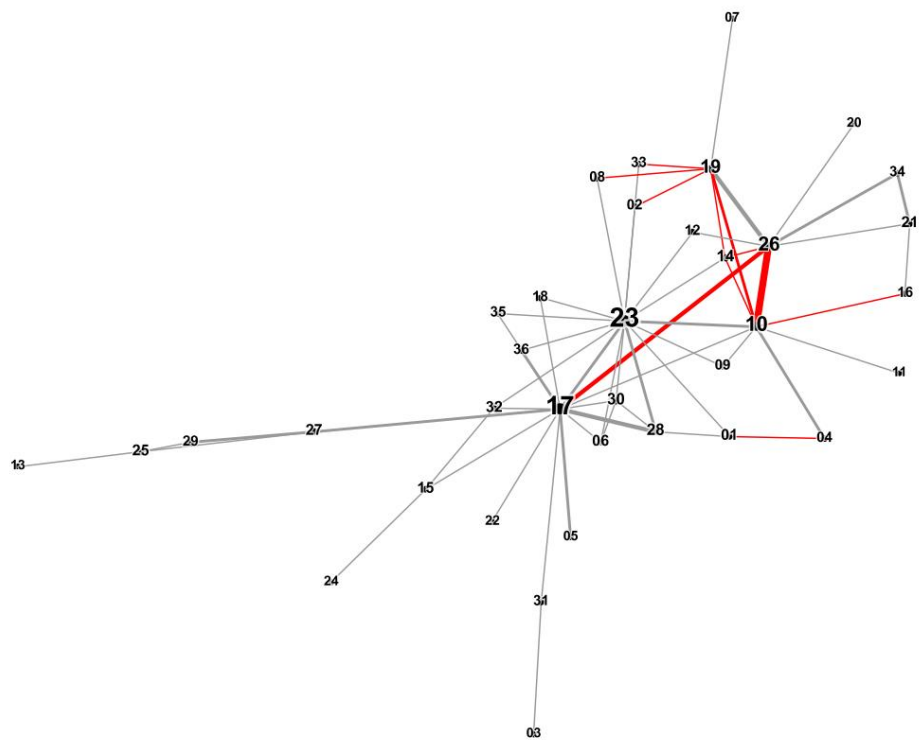

Grafik 6. Analisa jaringan pertukaran dalam tindak korupsi tukar guling kawasan hutan Bogor

Keterlibatan mantan Bupati Bogor (No. 26) ini menjadi pintu masuk untuk melihat aliran pertukaran/ transaksi/ materi yang dipertukarkan. Transaksi materi berawal dari aktor No. 17, presiden komisaris perusahaan, yang diteruskan kepada karyawan kepercayaannya, aktor No. 10. Selanjutnya, transaksi merambah kepada aktor-aktor di pemerintahan, 
yakni aktor No. 1, 2, 8, 19, 14, dan 26. Dalam grafik kedua terlihat bahwa garis hubungan antara aktor No. 26 dan 10 lebih tebal dibanding yang lainnya. Hal tersebut menjelaskan bahwa kedua aktor tersebut yang paling berperan dalam pemberian izin tukar-menukar Kawasan hutan Bogor. Aktor No. 26 berperan dalam hal ini memberikan izin lewat Kepala Dinas Perhutanan dan Pertanian sangat penting dalam relasi jejaring korupsi. Di sinilah letak pentingnya lantaran sumber daya di antara sejumlah aktor bakal dipertukarkan nantinya.

\section{Kasus Korupsi Nomor 4: Kasus Korupsi Sawit Kutai Kartanegara}

Kasus korupsi suap pembukaan lahan perkebunan sawit bermula dari permohonan izin yang tak kunjung diberikan dari Pemerintah Kabupaten Kutai Kartanegara kepada PT SGP. Lantaran tak kunjung diberikan, pimpinan PT SGP (aktor No. 11) kemudian menyuap mantan Bupati Kabupaten Kutai Kartanegara saat yaitu RW (No. 28). Suap terebut diberikan langsung oleh Direktur Utama PT SGP HSG (No. 11) alias Abun secara bertahap kepada RW(No. 28) saat dirinya masih menjabat bupati.

Grafik 7. Analisa jaringan aktor dalam tindak korupsi sawit Kutai Kartanegara

Merujuk pada kasus tersebut, hasil SNA menunjukkan bahwa nama RW (No. 28) mendapatkan angka derajad sentralitas, sentralitas aktor dan juga kedekatan sentralitas tertinggi. Hal ini menunjukkan, bahwa aktor No. 28 merupakan aktor sentral sekaligus simpul penting bagi jejaring korupsi suap perizinan sawit dalam kasus ini. Selain menerima uang terkait perizinan perkebunan sawit, aktor No. 28 juga mengarahkan kepala-kepala dinas terkait untuk menindaklanjuti permintaan tersebut. Aktor dari institusi pemerintah yang terlibat dalam analisis kasus ini adalah nomor $6,7,9,17,18,31$, dan 33 . 


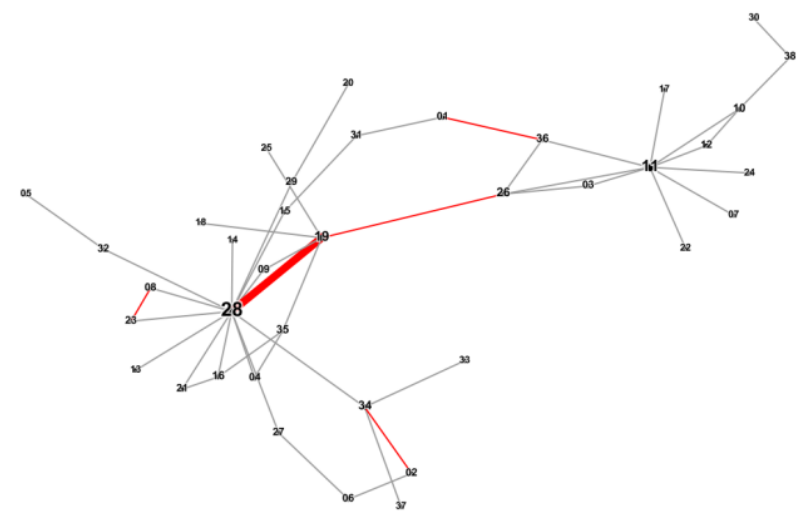

Grafik 8. Analisa jaringan pertukaran dalam tindak korupsi sawit Kutai Kartanegara

Grafik selanjutnya menunjukkan bagaimana transaksi/pertukaran/materi berlangsung. Grafik kedua menunjukkan aktor No. 28 memiliki garis merah yang lebih tebal dengan aktor No. 19 dibanding dengan yang lain. Hal ini karena aktor No. 19 , K, memiliki hubungan yang erat dengan RW. Dia diketahui telah menjadi tangan kanan sekaligus mantan tim pemenangan RW. Sehingga, tidak heran jika kedua aktor tersebut menjadi simpul dalam jejaring korupsi perizinan pembukaan lahan sawit di kasus Kutai ini.

Kasus Korupsi No. 5: Suap PT KPI (KPI) dan PT KOI kepada Kepala Kegiatan Usaha Hulu Minyak dan Gas Bumi SKK Migas

Kasus suap dalam sektor migas melibatkan dua perusahaan besar yaitu PT KPI dan PT KOI. Dalam kasus ini, petinggi kedua perusahaan tersebut menjadi tokoh kunci dalam korupsi migas dengan melibatkan Kepala SKK Migas. Berdasarkan hasil analisis menggunakan
SNA tampak bahwa AMS (No. 2) sebagai Presiden Direktur PT KPI menempati degree tertinggi bersama dengan $\mathrm{RR}$ (No.13) sebagai aktor kunci dari SKK Migas.

Aktor No.2 memiliki menjadi aktor kunci yang memiliki relasi dengan berbagai aktor, diantaranya yaitu No. 1, 3, 6, 8, 9, 10 dan 13. Relasi aktor No. 2 dengan aktor-aktor lain menjadi jalan bagi proses terjadinya korupsi. Hal ini terlihat ketika aktor No.2 terbukti memberikan AS $\$ 522,5$ kepada aktor No.13 melalui aktor No. 3 untuk memberikan rekomendasi berupa penyetujuan penurunan formula harga gas PT KPI kepada Menteri Energi dan Sumber Daya Mineral (ESDM). Peran aktor No.8 yang merupakan rekan kerja aktor No. 2 juga penting yaitu dengan mengirimkan Surat No. 001/KPI-MS/XI/2012 tanggal 12 November 2012 perihal Usulan Penyesuaian Formula Gas untuk PT KPI. Namun, usulan tersebut tidak disetujui dalam rapat Ditjen Migas karena akan menurunkan penerimaan negara. 


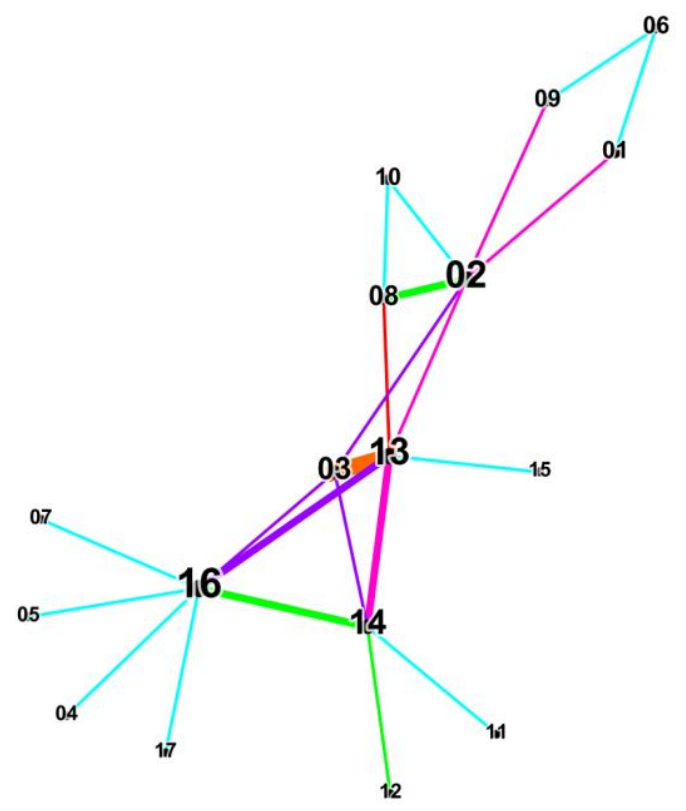

Derajad tertinggi : (02) \& (13)
$\begin{aligned} & \text { Kedekatan sentralitas tertinggi } \\ & \text { Sentralitas aktor tertinggi }:(13)\end{aligned}$

Grafik 9. Analisa jaringan aktor dalam tindak korupsi Suap PT KPI dan PT KOI

Dari sosiogram diatas, terlihat bahwa aktor No.13 selain memiliki degree tertinggi juga sekaligus memiliki kedekatan sentralitas tertinggi. Hal ini menunjukkan bahwa aktor ini memiliki banyak relasi dan juga memiliki kedekatan dengan aktor yang lain. Selain terlibat dalam kasus suap dengan PT KPI, aktor ini juga terlibat suap dengan PT KOI. Ia menerima uang sebesar 300 ribu dolar AS pada 26 Juli 2013 dan 400 ribu dolar AS pada 13 Agustus 2013 dari aktor No. 14 yang merupakan komisaris PT KOI. Transaksi suap yang dilakukan oleh kedua perusahaan dengan aktor No.13 melibatkan aktor No. 3 yang berperan sebagai penghubung/perantara. Aktor No. 3 yang merupakan pelatih golf dari aktor No. 13 bertugas menerima uang dari perusahaan untuk kemudian diberikan kepada aktor No. 13.

Sementara itu, aktor No. 16 memiliki betweenness tertinggi di dalam sosiogram. Aktor No. 16 merupakan adalah pengusaha Singapura yang mewakili empat perusahaan yaitu FE Ltd, KO Pte Ltd, FT Co. Ltd dan WPE Pte Ltd. Aktor No. 16 melakukan suap terkait dengan lelang terbatas minyak mentah dengan menggunakan aktor No. 14 sebagai penghubung.

Hasil analisis SNA menunjukkan materi yang dipertukarkan dalam kasus suap di sektor migas sebagaimana terlihat dalam gambar di bawah ini. Dalam kasus PT KPI , pertukaran materi terjadi dengan melibatkan aktor No. 2 dan 13. Untuk melancarkan proses suap ini, aktor No. 2 mendekati No. 01 dan 9 yang menjabat sebagai Dirjen Migas. Selain itu, transaksi juga melibatkan aktor No.3 yang memiliki kedekatan dengan aktor No.13.

Sementara itu, pertukaran materi juga tampak dalam interaksi antara aktor No. 13 dengan No. 16 dan 14. Garis tebal merah pada gambar diatas menunjukkan kuatnya pertukaran materi antar ketiga aktor ini. Aktor No. 13 yang menjabat sebagai Kepala SKK Migas pada tahun 2013, menjadi aktor sentral dalam transaksi suap dengan dua perusahaan ini. Sebagai timbal balik atas pemberian uang tersebut, aktor No.13 akhirnya memenuhi enam permintaan aktor No. 16. Pertama, menyetujui FE Ltd sebagai pemenang lelang terbatas kondesat Senipah bagian 
negara pada tanggal 7 Juni untuk periode Juli 2013. Kedua, menyetujui kargo pengganti minyak mentah GM bagian negara untuk periode Februari - Juli 2013 untuk FE Ltd. Ketiga, menggabungkan lelang terbatas minyak mentah minas/SLC bagian negara dan kondesat Senipah bagian negara untuk periode Agustus 2013. Keempat, menyetujui FE Ltd sebagai pemenang pada lelang terbatas minyak

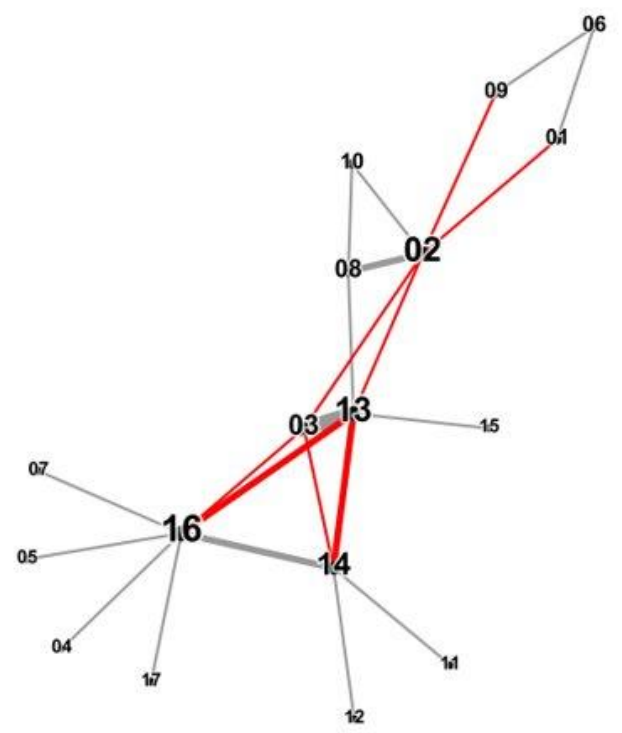

mentah minas/SLC bagian negara dengan kondensat Senipah bagian negara pada tanggal 4 Juli 2013 untuk periode Agustus 2013. Kelima, menggabungkan tender kondensat Senipah dan minyak mentah Duri untuk periode September-Oktober 2013. Keenam, menunda pelaksanaan tender kondesat Senipah periode September-Oktober 2013.

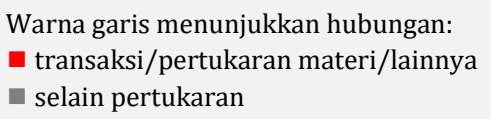

Grafik 10. Analisa jaringan pertukaran dalam tindak korupsi Suap PT KPI dan PT KOI kepada Kepala Kegiatan Usaha Hulu Minyak dan Gas Bumi SKK Migas

\section{Protokol Analisa Jaringan Sosial Korupsi di Sektor SDA}

Jaringan korupsi, khususnya korupsi sumber daya alam, di Indonesia telah lama dikaitkan dengan pengusaha, kepala daerah, dan struktur birokrasi yang korup. Namun, selama ini penindakan kasus korupsi hanya menyasar aktor utama. Padahal, di luar aktor utama, terdapat aktor pendukung yang memiliki peran yang tidak kalah penting dengan aktor utama dalam jaringan dan aktivitas korupsi. Kami menggunakan analisis jaringan sosial untuk memetakan jaringan korupsi sumber daya alam yang terbentuk di Indonesia, untuk mendalami bagaimana jaringan dibangun, signikansi peran setiap aktor, dan potensi pengembangan penindakan kasus korupsi.
Analisa jaringan sosial dapat menjadi salah satu metode analisis yang digunakan oleh Komisi Pemberantasan Korupsi untuk meningkatkan penyelidikan dan penindakan kasus korupsi. Analisa jaringan sosial dapat digunakan untuk mengkaji bagaimana jaringan korupsi terbentuk dan bekerja, serta melacak aktor-aktor pendukung yang kerap tersembunyi dan lolos dari tuntutan. Selain itu, melalui analisa jaringan sosial, aliran uang hasil korupsi dapat dilacak untuk mengetahui nominal, sumber, pemberi, perantara, dan penerima kentungan terbesar dari berlangsungnya aktivitas korupsi 


\section{Alur Analisis}

Secara garis besar, analisis dalam penelitian ini menggunakan 3 dataset $\mathrm{j}$ yakni: 1) perkara yang berkekuatan hukum tetap (Inkracht), 2) database jejak kasus di website KPK, dan 3) putusan pengadilan negeri/tinggi/mahkamah agung. Berikut tahapan analisis yang kami lakukan:

1. Crawling menggunakan metode scrapping pada perkara yang berkekuatan hukum tetap (inkracht) melalui https://www.kpk.go.id/id/publikas i/penanganan-perkara/inkracht;

2. Dari hasil crawling yeng telah dilakukan, dilakukan pemisahan antara korupsi SDA dan non-SDA;

3. Dari kasus SDA berkekuatan hukum tetap (inkracht), dapat diketahui informasi berupa: 1) nama terdakwa, 2) jenis kasus korupsi, 3) nama/instansi terkait kasus korupsi, 4) nomor putusan pengadilan negeri;

4. Kemudian nama terdakwa tersebut digunakan sebagai kata kunci untuk melakukan crawling data di database jejak kasus KPK melalui

https://acch.kpk.go.id/id/jejakkasus;

5. Crawling data jejak kasus tersebut akan menghasilkan beberapa informasi yakni nama, profesi, institusi, waktu kejadian perkara, waktu inkracht, area korupsi, jenis tindak pidana korupsi, dakwaan, tuntutan, putusan, dan deskripsi kasus;

6. Informasi yang didapat dari database jejak kasus kemudian diperdalam dengan data putusan pengadilan baik dari pengadilan negeri, pengadilan tinggi, maupun mahkamah agung yang bersifat final and binding. Putusan pengadilan memberikan informasi yang mendalam terkait dengan alur korupsi dan peran masingmasing aktor;

7. Dari informasi tiga dataset tersebut, kemudian diolah menggunakan metode analisa jaringan sosial, untuk melihat tautan antar aktor, kepentingan, dan manfaat yang dipertukarkan.

\section{Optimalisasi Analisis Jaringan Sosial dalam Pengungkapan Kasus Korupsi}

Salah satu kunci penting dari optimalisasi analisis jaringan sosial adalah kedalaman dan keberagaman data dari berbagai sumber. KPK dapat mempertimbangkan untuk menjalin kolaborasi dengan lembaga lain seperti lembaga penegak hukum dan akademisi untuk saling bertukar informasi dan akses terhadap data.

\section{Penutup}

Peta jaringan SNA menunjukkan bahwa terdapat dua bentuk jaringan SNA yang penting yaitu peta jaringan aktor dan peta jaringan sumber daya yang dipertukarkan. Aktor menjadi motor paling penting dalam jaringan korupsi sementara institusi menjadi bagian penjelas aktor dan bergerak mengikuti aktor. Meskipun demikian, kedudukan institusi dari aktor membedakan sumber daya yang dipertukarkan dalam tindak korupsi.

Aktor pejabat publik menggunakan kekuasaan dan otoritas yang kemudian dikonversi menjadi pemberian rekomendasi atau izin. Sedangkan aktor swasta menggunakan uang atau materiil yang kemudian dikonversi menjadi permohonan rekomendasi dan uang/materi suap.

Peta jaringan SNA aktor dan jaringan pertukaran menghasilkan enam temuan 
penting yaitu pertama relasi korupsi terbentuk berdasarkan hubungan saling ketergantungan antar aktor dalam mencapai tujuan. Kedua, para aktor tidak akan mampumencapai tujuan tanpa melibatkan pertukaran sumber daya yang dimiliki masing-masing aktor. Ketiga, jejaring korupsi SDA berakar dari relasi sosial pelbagai aktor dengan beragam kepentingan dan sumber daya. Keempat, relasi ini terbentuk secara berulang-ulang, terus-menerus dan saling mengunci satu sama lain (inter-locking). Kelima, jaringan korupsi membentuk 'institusi' sendiri yang menggerogoti institusi-institusi dalam sumber daya alam khususnya sektor migas dan kehutanan. Keenam, 'institusi' korup ini membelenggu baik itu sektor privat melalui mekanisme suap, dan sektor publik dengan otoritas perijinannya melalui pertukaran yang merugikan negara baik dari sisi integritas pejabat publik, sektor ekonomi dan menggerogoti hukum.

Tentu saja penelitian ini memiliki banyak kelemahan. Kelemahan utama penelitian ini adalah pertama pilihan data berbasis hukum/legal yang membatasi temuan. Kedua, pertukaran koruptif yang dilacak terbatas terhadap aspek material yang menyebabkan penelitian ini terjebak dalam pendekatan rasional. Ketiga, ketidaklengkapan data menyebabkan penelitian ini kurang sesuai dengan kriteria SNA-sentris standar. Keempat, singkatnya waktu penelitian selama sebulan menyebabkan pengembangan SNA menjadi tidak optimal.

Untuk itu, penelitian ini merekomendasikan pertama, KPK dapat melanjutkan penelitian dengan menggunakan data yang lebih lengkap seperti notulensi atau pun Berita Acara Pemeriksaan (BAP). Penelitian lanjutuan juga dapat dilakukan pihak lain untuk itu peneliti melampirkan protokol SNA dalam keterangan. Kedua, tindakan pencegahan dan penindakan korupsi tidak hanya membutuhkan pendekatan institusional dengan menitikberatkan pada Komisi Pemberantasan Korupsi. Namun, membutuhkan kerja sama, kolaborasi dari pelbagai pihak. Ketiga, perlu ada penguatan narasi bahwa tindakan pencegahan korupsi adalah tanggung jawab semua aktor dalam hal ini warga sebagai bangsa. Keempat, membangun narasi ini tidak hanya dilakukan secara sistemik melalui mekanisme pendidikan, namun juga dilakukan dalam mekanismemekanisme yang bersifat popular dan massal.

\section{Referensi}

Abdullah, Maryati, et al. (2017). Koordinasi dan Supervisi Pertambangan Mineral dan Batubara:LanjutCapaian Laporan. Publish What You Pay Indonesia. Jakarta.

Acemoglu Daron and James A. Robinson. (2012). Why Nations Fail: The Origins of power, Prosperit, and Poverty. Crown. New York.

Alfada, A. (2019). The destructive effect of corruption on economic growth in Indonesia: A threshold model. Heliyon 5(10): e02649. doi:10.1016/j.heliyon.2019.e02649.

Ali Mukartono, Hartiwiningsih, dan Muhammad Rustamaji. (2019). The Development of Corruption in Indonesia: is Corruption a Culture of Indonesia? Advances in Social Science, Education and Humanities Research 358.

Anti-Corruption Clearance House (ACCH). Materi Diskusi Melawan Korupsi di Sektor Sumber Daya Alam. Acch.kpk.go.id.

https://acch.kpk.go.id/id/artikel/p aper/materi-diskusi-melawankorupsi-di-sektor-sumber-dayaalam. 21 Mei 2020. 
Ashforth, B. E., \& Anand, V. (2003). The normalization of corruption in organizations. Research in organizational behavior 25: 1-52.

Badan Pusat Statistik. (2020). Berita Resmi Statistik pada 15 Februari 2020. https://www.bps.go.id/website/ma teri_ind/materiBrsInd20200205114932_.pdf . 24 Mei 2020.

Baker, Jacqui. (2020). Corrupt networks in the Indonesian forests sector: politics and pulp in Pelalawan, Riau. Anti-Corruption Resource Centre, Chr. Michelsen Institute (U4 Issue 2020:12).

https://www.u4.no/publications/c orrupt-networks-in-the-

indonesian-forestry-sector.

Bhattacharyya, S., \& Hodler, R. (2010). Natural resources, democracy and corruption. European Economic Review 54(4)608-621.

Bjørnskov, C. (2011). Combating Corruption: On the Interplay between Institutional Quality and Social Trust. The Journal of Law \& Economics 54(1): 135-159. doi:10.1086/652421

Boyke P. Siregar. Korupsi Semakin Masif, KPK Ubah Strategi Pemberantasan dan Pencegahan.

WartaEkonomi.co.id.

https://www.wartaekonomi.co.id/r ead37993/korupsi-semakin-masifkpk-ubah-strategi-pemberantasandan-pencegahan.html. 22 Juli 2020.

Brunetti, A., \& Weder, B. (2003). A Free Press is Bad NEws for Corruption. Journal of Public Economics 87(78): 1801-1824.

Carrington, P. J., Scott, J., \& Wasserman, S. (Eds.). (2005). Models and Methods in Social Network Analysis (Vol. 28). Cambridge University Press.
Chowdhury, S. K. (2004). The Effect of Democracy and Press Freedom on Corruption: An Empirical Test. Economics Letters 85:93-101.

Creswell, J. W., \& Poth, C. N. (2016). Qualitative inquiry and research design: Choosing among five approaches. Sage Publications.

De Graaf, Gjalt., \& L.W.J.C. Huberts. (2008). Portraying the Nature of Corruption Using an Explorative Case Study Design. Public Administration Review July-August 2008.

De Nooy, Wouter, Andrej Mrvar, and Vladimir Batagelj. (2018). Exploratory social network analysis with Pajek: Revised and expanded edition for updated software Vol. 46. Cambridge University Press.

Dewi, Tresya, dkk. (2019). Penataan Perizinan dalam Gerakan Nasional Penyelamatan Sumber Daya Alam di Indonesia. Jurnal Antikorupsi INTEGRITAS 05(2): 15-31.

Domandenik, Polona., Janez Prašnikar, \& Jan Svejnar. (2016). Political Connectedness, Corporate Governance, and Firm Performance. J Bus Ethics 139: 411428. doi 10.1007/s10551-0152675-4

Dreher, A., \& Schneider, F. (2010). Corruption and the Shadow Economy: an Empirical Analysis. Public Choice 144: 215-238. doi: 10.1007/s11127-009-9513-0

F. Robertson-Snape. (1999). Corruption, Collusion and Nepotism in Indonesia. Third World Quarterly 20(3): 589-602.

Fajar Pebrianto. (2020). Kontroversi UU Minerba yang Bakal Diujimaterikan ke MK. Tempo.co, 13 Mei 2020. https://fokus.tempo.co/read/1341 880/kontroversi-uu-minerba-yang- 
bakal-diujimaterikan-ke-mk. 21 Mei 2020.

Farrales, M. J. (2005). What is Corruption? A History of Corruption Studies and the Great Definitions Debate. SSRN.

doi:http://dx.doi.org/10.2139/ssrn. 1739962.

Gokcekus, O., \& Knorich, J. (2006). Does Quality of Opennes Affect Corruption? Economic Letters 91: 190-196.

Gokcekus, O., \& Yuuki, Y. (2011). Business Cycle and Corruption. Economic Letters 111(2): 138-140. doi:https://doi.org/10.1016/j.econl et.2011.01.023.

Gymah-Brempong, Kwabena. (2002). Corruption, economic growth, and income inequality in Africa. Economics of Governance volume 3 , pages183-209

Hafner-Burton, Emilie M. and Montgomery, Alexander $\mathrm{H}$., (2010). Centrality in Politics: How Networks Confer Power. Paper 9. http://opensiuc.lib.siu.edu/pnconfs _2010/9

Hariadi Kartodiharjo, dkk. (2019). Kebijakan Pencegahan Korupsi Sektor Sumber Daya Alam Melalui Pendekatan Institusional dan Struktural. Jurnal Antikorupsi INTEGRITAS 5(2): 33-47.

Hellmann, 0. (2017). The historical origins of corruption in the developing world: a comparative analysis of East Asia. Crime, Law and Social Change 68(1-2): 145-165.

Herman. INDEF: Korupsi Hambat Investasi dan Pertumbuhan Ekonomi. Beritasatu.com, 30 September 2019.

https://www.beritasatu.com/ekon omi/577619-indef-korupsi-

hambat-investasi-dan- pertumbuhan-ekonomi. 30 Juli 2020.

Indonesian Mining Institute. (2018). Report on Indonesia Mining Sector Diagnostic. World Bank, Washington, DC. World Bank. Diakses pada 24 Mei 2020, lewat laman

https://openknowledge.worldban k.org/handle/10986/33087.

Jean Cartier-Bresson. (1997). Corruption Networks, Transaction Security and Illegal Social Change. Political Studies XLV: 463-476.

John Osburg. (2018). Making Business Personal: Corruption, AntiCorruption, and Elit Networks in Post-Mao China. Current Anthropology 59(18): 149-159.

Johnston, M. (2005). Syndromes of Corruption: Wealth, Power and Democracy. CUP. Cambridge.

Kaesar Akbar. Menteri Johan Sebut PNBP Sektor ESDM Capai Rp 217,5 Triliun. Tempo.co, 4 Januari 2019. https://bisnis.tempo.co/read/1161 685/menteri-jonan-sebut-pnbpsektor-esdm-capai-rp-2175-triliun. 24 Mei 2020.

Khan, M. (2000). Rent-Seeking as Process. In M. Khan, \& K. S. Jomo (Eds.), Rents, Rent-Seeking and Economic Development. CUP. Cambridge.

Kolstad, I., Fritz, V., \& O’Neil, T. (2008). Corruption, Anti-Corruption Efforts and Aid: Do Donors Have the Right Approach? Working Paper Good Governance, Aid Modalities and Poverty Reduction: Linkages to the Millenium Development Goals and Implications for Irish Iad.

Konsorsium Pembaharuan Agraria. (2018). Masa depan Reforma Agraria Melampaui Tahun Politik: Catatan Akhir Tahun 2018 Konsorsium Pembaharuan Agraria. 
Kajian Korupsi sebagai Proses Sosial:

Melacak Korupsi di Sektor Sumber Daya Alam di Indonesia

Konsorsium Pembaharuan Agraria. Jakarta.

Kumparan News. Pengesahan UU Minerba: Kecurangan saat Corona, Berpihak pada Korporat Batubara. Kumparan.com, 15 Mei 2020. https://kumparan.com/kumparan news/pengesahan-uu-minerbakecurangan-saat-corona-berpihakpada-korporat-batu-bara1tPzyuZNShD. 21 Mei 2020.

Laode, Mohmmad Syarif. (2020). Forum Group Discussion (FGD). Sleman, 16 Oktober 2020.

M. Ganie-Rochman \& R. Achwan. (2016). Corruption in Indonesia's Emerging Democracy. Journal of Developing Societies 32(2):159177.

MacMullen, R. (1988). Corruption and the Decline of Rome. Yake University Press. New Haven.

Marcus, Mietzner. (2015). Dysfunction by Design: Political Finance and Corruption in Indonesia. Critical Asian Studies 47(4): 587-610. DOI: 10.1080/14672715.2015.107999 1.

Mauro, P. (1995, Agustus). Corruption and Growth. The Quarterly Journal of Economics 110(3): 681-712. Retrieved from http://www.jstor.org/stable/294 6696

Mehlum, H., Moene, K., \& Torvik, R. (2006). Institution and the Resource Curse. The Economic Journal 116(508): 120.

Méon, P., \& Sekkat, K. (2005). Does Corruption Grease or Sand the Wheels of Growth? Public Choice 122: 69-97.

Michael J. Miller. Persistent Illegal Logging in Costa Rica: The Role of Corruption Among Forestry
Regulators. Journal of Environment \& Development, Volume 20 Nomor 1 2011:50-68. DOI: $10.1177 / 107049651039431$.

Mumu Muhajir, dkk. (2019). Harmonisasi Regulasi dan Perbaikan Tata Kelola Sumber Daya Alam di Indonesia. Jurnal Antikorupsi INTEGRITAS 05(2): 1-13.

P. X. To, S. Mahanty, \& W. Dressler. (2014). Social Networks of Corruption in the Vietnamese and Lao CrossBorder Timber Trade. Anthropological Forum 24(2): 154-174. doi:10.1080/00664677.2014.89350 5 .

Palmer, D. (2008). Extending the process model of collective corruption. Research in organizational behavior 28: 107-135.

Potrafke, N. (2011). Intelegence and Corruption. Working Paper Series. Retrieved from http://www.unikonstanz.de/FuF/wiwi/workingpa perseries/WP_36-Potrafke-11.pdf

PSHK dan Kementerian PPN/Bappenas. (2019). Kajian Reformasi Regulasi di Indonesia: Pokok Permasalahan dan Strategi Penanganannya. YSHK. Jakarta.

R. S. Burt. (1978). Applied Network Analysis: An overview. Sociological Methods \& Research 7(2): 123-130.

Robbins, P. (2000). The rotten institution: corruption in natural resource management. Political Geography 19(4): 423-443.

Rose-Ackerman, S., \& Søreide, T. (Eds.). (2012). International Handbook on the Economics of Corruption (Vol. 2). Edward Elgar Publishing. Cheltenham.

S. Wasserman, \& K. Faust. (1994). Social Network Analysis: Methods and 
Applications (Vol. 8). Cambridge University Press. New York.

Sania Mashabi. Pengesahan UU Minerba, untuk Siapa? Kompas.com, 14 Mei 2020.

https://nasional.kompas.com/read /2020/05/14/06215741/pengesah an-uu-minerba-untuk-siapa. $21 \mathrm{Mei}$ 2020

Scott, J. P. (2000). Social Network Analysis: A Handbook. SAGE Publications.

Shleifer \& R.W. Vishny. (1993). Corruption. The Quarterly Journal of Economics 108(3): 599-617. doi:10.2307/2118402.

Stevens, A. (2016). Configurations of corruption: a cross-national qualitative comparative analysis of levels of perceived corruption. International Journal of Comparative Sociology 57(4): 183206.

Strong, Colin. (2015). Humanizing big data: Marketing at the meeting of data, social science and consumer insight. Kogan Page Publishers.
Tiantian Zheng. (2006). Cool Masculinity: Male Clients' Cex Consumption and Business Alliance in Urban China's Sex Industry. Journal of Contemporary China, 15: 161-182.

Wank, David. (1999). Commodifying Communism: Business, Trust, and Politics in a Chinese City. Cambridge University Press. New York.

Warburton, J. (2013). Corruption as a social process. Corruption and anticorruption.

Zheng Chang. (2018). Understanding the Corruption Networks Revealed in the Current Chinese Anticorruption Campaign: A Social Network Approach. Journal of Contemporary China 27(113): 735747. doi: 10.1080/10670564.2018.1458060. 